\title{
Research Paper Awareness and consumer behaviour towards coconut milk powder : A value added coconut product
}

- Sachu Zachariah John and K.N. Ushadevi

See end of the paper for authors' affiliations

Correspondence to :

Sachu Zachariah John

Kerala Livestock

Development Board,

Kulathupuzha (Kerala)

India

Email: sachuzj@yahoo.com

Paper History :

Received : 11.01.2020;

Revised : 14.02.2020;

Accepted : 21.02 .2020
ABSTRACT : The awareness and the consumption pattern of coconut milk powder (CMP) among consumers in three districts of Kerala viz.,Trivandrum, Ernakulam and Kozhikode which are placed almost equidistantly along the length of Kerala and representing southern, central and northern zones were studied by pre-tested structured interview. CMP is produced by spray drying of coconut milk and can be reconstituted into coconut milk by diluting it with water. The respondents selected were from elite class in the urban centres. Out of 376 consumers interacted 66 and 58 per cent of them were found to be aware and purchasing and using CMP, respectively. Out of those who were aware 88 per cent were purchasing/using it. Ninety six per cent of the respondents were graduates or post graduates. Thirty-one per cent of the total respondents were businessmen, 14 per cent each were NRIs, private employees and housewives and 11 per cent were government employees. Monthly income of 79 per cent of the total respondents ranged from Rs. 0.75 to 1.5 lakhs. The monthly expenditure for CMP was found to be Rs. 573 corresponding to 5.7 and 2.4 percentage to food and food plus non-food expenditure, respectively. The consumption pattern of consumers revealed high market potential for CMP and the marketers may try to take advantage of this situation. Regional differences observed in the awareness may be due to the inappropriate and inadequate distribution of the products to which the marketers should give more attention. Frequency of purchase of CMP limited to fortnightly to monthly intervals, however, 38 per cent of the respondents did not keep any specific interval for purchasing the same which suggested that the stock and supply should be regulated for continuous supply of products to the consumers. Since CMP is an upcoming product in the market irrespective of rural and urban areas appropriate awareness and promotional activities should be conducted by the marketers.

KEY WORDS : Consumer profile, Consumer awareness, Consumption pattern, Coconut milk powder

HOW TO CITE THIS PAPER : John, Sachu Zachariah and Ushadevi, K.N. (2020). Awareness and consumer behaviour towards coconut milk powder : A value added coconut product. Internat. Res. J. Agric. Eco. \& Stat., 11 (1) : 87-93, DOI : 10.15740/HAS/IRJAES/11.1/87-93. Copyright@2020:HindAgri-Horticultural Society. 